\title{
Rubritalea halochordaticola sp. nov., a carotenoid- producing verrucomicrobial species isolated from a marine chordate
}

\author{
Jaewoo Yoon, ${ }^{1 \dagger}$ Satoru Matsuda, ${ }^{2}$ Kyoko Adachi, ${ }^{2+\dagger}$ Hiroaki Kasai ${ }^{2+\dagger \dagger}$ \\ and Akira Yokota ${ }^{1}$ \\ ${ }^{1}$ Institute of Molecular and Cellular Biosciences, The University of Tokyo, 1-1-1 Yayoi, Bunkyo-ku, \\ Tokyo 113-0032, Japan \\ ${ }^{2}$ Marine Biotechnology Institute Co. Ltd, 3-75-1 Heita, Kamaishi, Iwate 026-0001, Japan
}

Correspondence
Jaewoo Yoon
jwyoon@kmu.ac.kr

The phylum 'Verrucomicrobia' (Hedlund et al., 1997) represents a primary lineage within the bacterial phylogenetic tree and contains a number of environmental species as well as a small number of cultured species. The genus Rubritalea (Scheuermayer et al., 2006) is a member of this phylum and consists of several marine species such as Rubritalea marina (Scheuermayer et al., 2006), Rubritalea squalenifaciens (Kasai et al., 2007), Rubritalea spongiae (Yoon et al., 2007), Rubritalea tangerina (Yoon et al., 2007) and Rubritalea sabuli (Yoon et al., 2008). These species were isolated from marine invertebrates and marine sediments and appeared as reddish pink-coloured colonies following their culture with various types of seawater media containing polysaccharides, amino acids, vitamins

tPresent address: College of Pharmacy, Keimyung University, 2800 Dalgubeoldaero, Dalseo-Gu, Daegu 704-701, Republic of Korea.

t†Present address: Basic Research Laboratories, Nippon Steel Chemical Co., Ltd, 1 Tsukiji, Kisarazu, Chiba 292-0835, Japan.

t†tPresent address: Marine Biosciences Kamaishi Research Laboratory, Kitasato University, 3-75-1 Heita, Kamaishi, Iwate 0260001, Japan.

The GenBank/EMBL/DDBJ accession number for the 16S rRNA gene sequence of Rubritalea halochordaticola MN1-1006 ${ }^{\top}$ is $\mathrm{AB} 543683$. and antibiotics. The four latter species were found to be squalene- and carotenoid-producing bacteria. Carotenoidproducing isolates are potential genetic resources for isoprenoid pigments of industrial and nutritional interest. Carotenoids are an abundant group of isoprenoid pigments synthesized by all photosynthetic organisms and some non-photosynthetic bacteria and fungi. Carotenoids such as lycopene also act as natural antioxidants that could help to prevent some types of human cancer and degenerative diseases (Fraser \& Bramley, 2004). Moreover, the colourant and aromatic properties of some carotenoids and derived compounds have an important industrial value (Bartley \& Scolnik, 1995; Sandmann, 2001; Fraser \& Bramley, 2004). Recently, a novel acyl glyco-carotenoid, diapolycopenedioic acid xylosyl ester, possessing antioxidative activities was discovered in $R$. squalenifaciens HOact $23^{\mathrm{T}}$ (Shindo et al., 2007). In this study, we attempted to elucidate the phylogenetic position of a novel carotenoid-producing bacterium, strain $\mathrm{MN} 1-1006^{\mathrm{T}}$ isolated from a marine ascidian, using a polyphasic taxonomic approach including 16S rRNA gene sequence analysis. Based on these data, it is proposed that the new isolate represents a novel species of the genus Rubritalea within the phylum 'Verrucomicrobia'. 
Strain MN1-1006 ${ }^{\mathrm{T}}$ was isolated from an ascidian sample collected by scuba diving near the arch-like configuration of Himezu Port, Sado Island, Niigata Prefecture, Japan, in December 2006. The tissue sample $\left(0.5-1.0 \mathrm{~cm}^{3}\right)$ was homogenized with a glass rod in $5 \mathrm{ml}$ sterile seawater. A $50 \mu \mathrm{l}$ sample of the homogenate was applied to the surface of an agar plate containing medium M1 (Mincer et al., 2002). Strain MN1-1006 ${ }^{\mathrm{T}}$ appeared after incubation for 30 days at $25{ }^{\circ} \mathrm{C}$. The reddish pink-pigmented colony was purified on M1 agar after being cultivated for 710 days.

The temperature range and $\mathrm{pH}$ range for growth were determined by incubating the isolates on $1 / 2$ strength R2A agar (Difco) with $75 \%$ artificial seawater (Lyman \& Fleming, 1940). The $\mathrm{NaCl}$ concentration for growth was determined on $1 / 2$ strength R2A agar containing $0-10 \%$ (w/v) NaCl. Gram-staining was performed as described by Murray et al. (1994). Cell morphology was observed using light microscopy (BX60; Olympus). Growth under anaerobic conditions was determined after 2 weeks of incubation in an AnaeroPack (Mitsubishi Gas Chemical Co., Inc.) on $1 / 2$ strength R2A agar (Difco) with $75 \%$ artificial seawater. Catalase activity was determined by bubble formation in a $3 \% \mathrm{H}_{2} \mathrm{O}_{2}$ solution. Oxidase activity was determined by cytochrome oxidase paper (Nissui Pharmaceutical Co., Ltd). API 20NE and API ZYM strips (bioMérieux) were used to determine the physiological and biochemical characteristics of the novel strain. All suspension media for the API test strips were supplemented with $0.85 \%(\mathrm{w} / \mathrm{v}) \mathrm{NaCl}$ solution (final concentration). API $20 \mathrm{NE}$ and API ZYM strips were read after $24 \mathrm{~h}$ incubation at $30^{\circ} \mathrm{C}$ and $4 \mathrm{~h}$ incubation at $37{ }^{\circ} \mathrm{C}$, respectively. The substrate oxidation range of strain MN1-1006 ${ }^{\mathrm{T}}$ was determined using Biolog MicroPlates.

Determination of the respiratory quinone system and cellular fatty acid composition were carried out as described previously (Katsuta et al., 2005). For the analysis of cellular fatty acid composition, bacterial strains investigated in the present and previous studies were grown on marine broth (Difco) for a week at $30{ }^{\circ} \mathrm{C}$. DNA was extracted and purified from cells grown on $1 / 2$ strength R2A agar with $75 \%$ artificial seawater according to the method of Marmur (1961). The DNA base composition was determined by using the HPLC method of Mesbah et al. (1989).

DNA-DNA hybridization tests were performed with photobiotin-labelled probes in microplate wells as described by Ezaki et al. (1989). The hybridization temperature was set at $46{ }^{\circ} \mathrm{C}$. Hybridization was performed with five replicates. Of the values obtained, the highest and lowest value for each sample was excluded and the means of the remaining three values are quoted as the final DNADNA relatedness values.

Cell walls were prepared according to the methods described by Schleifer \& Kandler (1972). The amino acids in an acid hydrolysate of the cell walls were identified by TLC (Harper \& Davis, 1979) and by HPLC, as their phenylthiocarbamoyl derivatives, with HPLC apparatus (LC-10AD; Shimadzu) equipped with a Wakopak WS-PTC column (Wako Pure Chemical Industries) (Yokota et al., 1993).

An approximately $1500 \mathrm{bp}$ fragment of the 16S rRNA gene was amplified from the extracted DNA by using bacterial universal primers specific to the $16 \mathrm{~S}$ rRNA gene: $27 \mathrm{~F}$ and 1492R (Escherichia coli numbering system; Weisburg et al., 1991). To ascertain the phylogenetic position of the new isolate, the $16 \mathrm{~S}$ rRNA gene sequence of strain MN1-1006 ${ }^{\mathrm{T}}$ was compared with sequences obtained from GenBank (National Center for Biotechnology Information, http://www.ncbi.nlm.nih.gov). Multiple alignments of the sequences were performed using CLUSTAL_X (version 1.83) (Thompson et al., 1997). Alignment gaps and ambiguous bases were not taken into consideration when the 1404 bases of the 16S rRNA gene nucleotides were compared. Aligned sequences were analysed with MEGA3.1 software (Kumar et al., 2004). Distances were calculated by using the Kimura two-parameter model (Kimura, 1983). Clustering with the neighbour-joining method (Saitou \& Nei, 1987) was determined by using bootstrap values based on 1000 replications (Felsenstein, 1985). The similarity values were calculated using the same software.

Cells of strain MN1-1006 ${ }^{\mathrm{T}}$ grown on $1 / 2$ strength R2A agar were rod-shaped, ranging from 0.5 to $0.8 \mu \mathrm{m}$ in width and from 1.0 to $1.5 \mu \mathrm{m}$ in length. Cell motility due to flagella or gliding was not observed. Cell division occurred by binary fission only.

On the basis of 16S rRNA gene sequence analysis, strain MN1-1006 ${ }^{\mathrm{T}}$ was found to be closely related to the genus Rubritalea within the phylum 'Verrucomicrobia' (Fig. 1). Comparative phylogenetic analysis of the $16 \mathrm{~S}$ rRNA gene sequences also showed that the sequence of strain MN1-1006 ${ }^{\mathrm{T}}$ had a high similarity of $>99 \%$ to the marine representatives $R$. squalenifaciens HOact $23^{\mathrm{T}}$ and $R$. sabuli YM29- $052^{\mathrm{T}}$, followed by $R$. marina Pol012 ${ }^{\mathrm{T}}(93.5 \%), R$. tangerina YM27-005 ${ }^{\mathrm{T}}(93.3 \%)$ and $R$. spongiae $\mathrm{YM} 21-132^{\mathrm{T}}$ $(93.3 \%)$. All other cultivated species of the family Verrucomicrobiaceae with validly published names were more distantly related.

The mean DNA-DNA hybridization values between strain MN1-1006 ${ }^{\mathrm{T}}$ and R. squalenifaciens HOact $23^{\mathrm{T}}$ and R. sabuli YM29- $052^{\mathrm{T}}$ were $57 \%$ and $14.5 \%$, respectively (Table 1 ). These results strongly suggested that strain MN1-1006 ${ }^{\mathrm{T}}$ could represent a separate and independent species (Wayne et al., 1987).

Analysis of the reddish pink pigments produced by strain MN1-1006 ${ }^{\mathrm{T}}$ was performed using HPLC/photodiode array detection (HPLC/PAD)/atmospheric pressure chemical ionization (APCI)-MS (Thermo Finnigan) of crude acetone extract from frozen cells. The pigment peaks detected by HPLC/PAD/APCI-MS showed a UV-visible spectrum with 


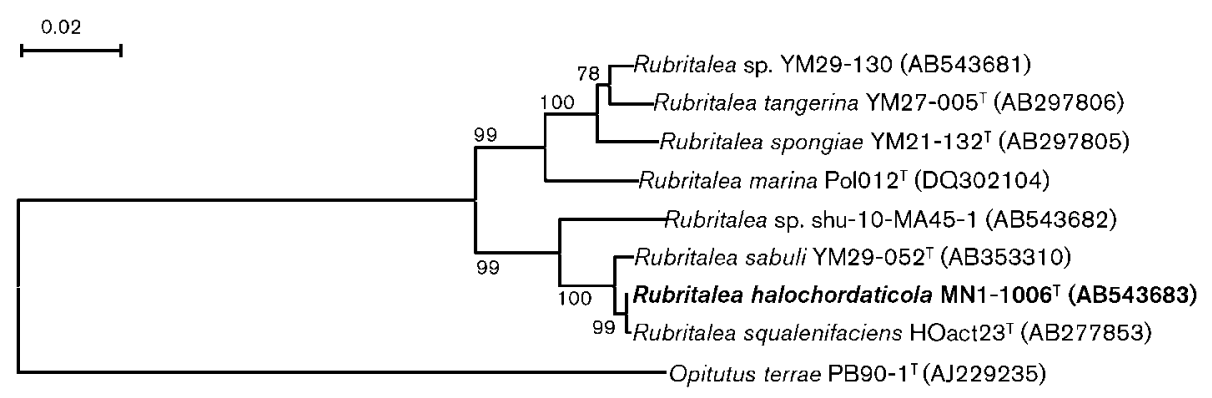

Fig. 1. Neighbour-joining tree showing the phylogenetic relationship of strain $M N 1-1006^{\top}$ and all recognized cultivated species of the genus Rubritalea within the phylum 'Verrucomicrobia' based on 16S rRNA gene sequences. Numbers at nodes are percentage bootstrap values derived from 1000 replications. The sequence of Opitutus terrae PB90-1 $1^{\top}$ was used as an outgroup. Bar, $2 \%$ estimated difference in nucleotide sequence.

absorption maxima at 494 and $522 \mathrm{~nm}$. This spectrum was similar to that of the novel carotenoid produced by $R$. squalenifaciens HOact $23^{\mathrm{T}}$ (Shindo et al., 2007). However, the molecular-related ion peak of the carotenoid could not be identified in the MS spectrum because of the presence of many peaks from other components in the extract. Squalene was also detected in the new isolate.

The predominant cellular fatty acids of the novel strain were iso- $\mathrm{C}_{14: 0}(54.7 \%)$, iso- $\mathrm{C}_{16: 0}(30.1 \%)$ and anteiso$\mathrm{C}_{15: 0}(9.3 \%)$, which were similar to those found for other members of the genus Rubritalea (Table 2). However, strain MN1-1006 ${ }^{\mathrm{T}}$ could be distinguished from the other species in the genus Rubritalea by the different proportions of fatty acids $\mathrm{C}_{15: 0}, \mathrm{C}_{15: 1} \omega 6 c$ and $\mathrm{C}_{16: 1} \omega 7 c$. In addition, strain MN1-1006 ${ }^{\mathrm{T}}$ could be distinguished from the other species of the genus Rubritalea by the physiological and biochemical properties given in Table 3 . The cell walls of the new isolate were prepared by disrupting cells, followed by heating with $3 \%$ SDS, washing and centrifugation. Amino acid analysis of the cell-wall hydrolysate indicated the presence of muramic acid and meso-diaminopimelic acid as the diagnostic diamino acids of the cell-wall peptidoglycan of strain MN1-1006 ${ }^{\mathrm{T}}$.

Based on the results of this polyphasic taxonomic study, strain MN1-1006 ${ }^{\mathrm{T}}$ warrants description as a novel species

Table 1. DNA-DNA hybridization values between strain $\mathrm{MN} 1-1006^{\top}$ and type strains of related members of the genus Rubritalea

\begin{tabular}{|lccc|}
\hline Strain & \multicolumn{2}{l|}{$\begin{array}{l}\text { DNA-DNA relatedness values } \\
\text { (\%) with labelled probes of: }\end{array}$} \\
\cline { 2 - 4 } & $\mathbf{1}$ & $\mathbf{2}$ & $\mathbf{3}$ \\
\hline 1. MN1-1006 $^{\mathrm{T}}$ & - & 58 & 12 \\
2. R. squalenifaciens $\mathrm{HOact}^{\mathrm{T}} 3^{\mathrm{T}}$ & 56 & - & 23 \\
3. R. sabuli $\mathrm{YM} 29-052^{\mathrm{T}}$ & 17 & 28 & - \\
\hline
\end{tabular}

of the genus Rubritalea. The name Rubritalea halochordaticola sp. nov. is proposed.

\section{Description of Rubritalea halochordaticola sp. nov.}

Rubritalea halochordaticola [ha.lo.chor.da.ti'co.la. Gr. n. hals halos sea; N.L. pl. n. Chordata scientific name of an animal phylum; L. suff. -cola (from L. n. incola) inhabitant; N.L. n. halochordaticola inhabitant of marine chordates].

Table 2. Comparison of the cellular fatty acid contents of strain MN1-1006 ${ }^{\top}$ and type strains of related species of the genus Rubritalea

Strains: 1, MN1-1006 ${ }^{\mathrm{T}} ; 2$, R. sabuli YM29-052 ${ }^{\mathrm{T}}$ (data from Yoon et al., 2008); 3, R. marina Pol012 ${ }^{\mathrm{T}}$ (Scheuermayer et al., 2006); 4. $R$. squalenifaciens HOact $23^{\mathrm{T}}$ (Kasai et al., 2007); 5, R. spongiae YM21$132^{\mathrm{T}}$ (Yoon et al., 2007); 6. R. tangerina YM27-005 $5^{\mathrm{T}}$ (Yoon et al., 2007). Values are percentages of total fatty acids; values $<1 \%$ are not shown. ND, Not determined; -, not detected; tr, trace.

\begin{tabular}{|lcccccc|}
\hline Fatty acid & $\mathbf{1}$ & $\mathbf{2}$ & $\mathbf{3}$ & $\mathbf{4}$ & $\mathbf{5}$ & $\mathbf{6}$ \\
\hline Saturated & & & & & & \\
$\mathrm{C}_{14: 0}$ & $\operatorname{tr}$ & $\operatorname{tr}$ & $\mathrm{ND}$ & $\operatorname{tr}$ & $\operatorname{tr}$ & 2.9 \\
$\mathrm{C}_{15: 0}$ & - & 1.0 & 4.5 & 1.9 & 2.6 & 1.4 \\
$\mathrm{C}_{16: 0}$ & 1.9 & 2.5 & 23.0 & 4.4 & 7.3 & 23.1 \\
$\mathrm{C}_{17: 0}$ & - & - & $\mathrm{ND}$ & $\operatorname{tr}$ & 2.8 & 1.1 \\
$\mathrm{C}_{18: 0}$ & - & - & $\mathrm{ND}$ & $\operatorname{tr}$ & $\operatorname{tr}$ & 2.4 \\
Unsaturated & & & & & & \\
$\mathrm{C}_{15: 1} \omega 6 c$ & - & 2.1 & $\mathrm{ND}$ & 1.0 & 2.0 & $\operatorname{tr}$ \\
$\mathrm{C}_{16: 1} \omega 7 c$ & 2.0 & 7.0 & 21.5 & 7.0 & 11.8 & 12.7 \\
$\mathrm{C}_{18: 1} \omega 7 c$ & - & - & $\mathrm{ND}$ & - & - & 1.5 \\
Branched & & & & & & \\
iso-C $\mathrm{C}_{14: 0}$ & 54.7 & 49.4 & 22.0 & 43.1 & 40.6 & 35.5 \\
iso- $\mathrm{C}_{16: 0}$ & 30.1 & 29.1 & $\mathrm{ND}$ & 20.6 & 16.1 & 12.2 \\
anteiso- $\mathrm{C}_{15: 0}$ & 9.3 & 5.1 & 6.0 & 18.1 & 12.9 & 4.7 \\
anteiso-C & & & \\
& $\operatorname{tr}$ & 1.3 & $\mathrm{ND}$ & 1.6 & 2.0 & - \\
\hline
\end{tabular}


Table 3. Physiological and biochemical characteristics of strain $\mathrm{MN} 1-1006^{\top}$ compared with those of related type strains of species of the genus Rubritalea

Strains: 1, MN1-1006 ${ }^{\mathrm{T}}$; 2, R. sabuli YM29-052 ${ }^{\mathrm{T}}$ (data from Yoon et al., 2008); 3, R. marina Pol012 ${ }^{\mathrm{T}}$ (Scheuermayer et al., 2006); 4. R. squalenifaciens HOact23 ${ }^{\mathrm{T}}$ (Kasai et al., 2007); 5, R. spongiae YM21-132 ${ }^{\mathrm{T}}$ (Yoon et al., 2007); 6. R. tangerina YM27-005 ${ }^{\mathrm{T}}$ (Yoon et al., 2007).

\begin{tabular}{|c|c|c|c|c|c|c|}
\hline Characteristic & 1 & 2 & 3 & 4 & 5 & 6 \\
\hline Source & Sea squirt & Marine sediment & Marine sponge & Marine sponge & Marine sponge & Sea hare \\
\hline Cell shape & Rod & Coccoid or rod & Coccoid or rod & Rod & Coccoid or rod & Coccoid or rod \\
\hline Colony colour & Reddish pink & Pink & Red & Reddish pink & Reddish pink & Reddish orange \\
\hline $\mathrm{O}_{2}$ requirement & $\begin{array}{c}\text { Obligately } \\
\text { aerobic }\end{array}$ & Obligately aerobic & Aerobic & Obligately aerobic & Obligately aerobic & $\begin{array}{c}\text { Facultatively } \\
\text { anaerobic }\end{array}$ \\
\hline $\mathrm{pH}$ range & $6.5-9.0$ & $6.5-8.5$ & $6.8-8.2$ & $7.5-8.5$ & $6.5-8.0$ & $6.5-8.5$ \\
\hline Temperature range $\left({ }^{\circ} \mathrm{C}\right)$ & $20-37$ & $10-37$ & $8-30$ & $15-37$ & $4-37$ & $15-37$ \\
\hline $\mathrm{NaCl}$ range (\%) & $1-7$ & $0-8$ & $1.4-3.8$ & $1-4$ & $1-7$ & $0-9$ \\
\hline \multicolumn{7}{|l|}{ Production of: } \\
\hline Catalase & + & + & - & + & + & - \\
\hline Oxidase & + & - & + & + & + & + \\
\hline Nitrate reduction & + & - & + & + & + & - \\
\hline \multicolumn{7}{|l|}{ Oxidation of: } \\
\hline Acetic acid & - & + & + & - & + & - \\
\hline Dextrin & + & + & + & - & - & - \\
\hline Cellobiose & - & + & + & - & - & - \\
\hline D-Glucuronic acid & + & + & - & + & - & - \\
\hline D-Mannose & - & + & + & - & - & + \\
\hline D-Mannitol & - & - & - & - & + & - \\
\hline Melibiose & - & + & + & + & + & - \\
\hline Formic acid & - & - & + & - & - & - \\
\hline $\begin{array}{l}N \text {-Acetyl-D- } \\
\text { galactosamine }\end{array}$ & + & + & - & + & - & - \\
\hline $\mathrm{N}$-Acetyl-D-glucosamine & + & + & - & + & - & - \\
\hline D-Sorbitol & - & - & - & - & + & - \\
\hline Trehalose & + & + & - & + & - & - \\
\hline L-Fructose & + & + & - & - & + & - \\
\hline L-Fucose & - & - & - & - & + & + \\
\hline D-Glucose & + & + & + & + & + & - \\
\hline cis-Aconitic acid & - & - & - & - & + & + \\
\hline Citric acid & - & - & - & - & - & + \\
\hline$\alpha$-Ketobutyric acid & - & - & - & - & + & - \\
\hline$\alpha$-Ketoglutaric acid & - & - & - & - & + & - \\
\hline Succinic acid & - & + & - & - & - & + \\
\hline Inosine & - & - & - & - & + & - \\
\hline Glucose 1-phosphate & - & - & - & - & + & + \\
\hline Glucose 6-phosphate & - & - & - & - & - & + \\
\hline \multicolumn{7}{|l|}{ Enzyme activity of: } \\
\hline Esterase (C4) & + & - & + & + & - & - \\
\hline Esterase lipase (C8) & - & - & + & + & - & - \\
\hline Leucine arylaminase & + & + & + & + & - & + \\
\hline Trypsin & - & - & + & - & - & - \\
\hline Chymotrypsin & + & - & - & + & - & - \\
\hline $\begin{array}{l}N \text {-Acetyl- } \beta \text { - } \\
\text { glucosaminidase }\end{array}$ & + & + & - & + & - & + \\
\hline$\alpha$-Fucosidase & - & - & - & - & + & - \\
\hline $\begin{array}{l}\text { DNA G }+ \text { C content } \\
(\mathrm{mol} \%)\end{array}$ & 51.4 & 47.7 & 50.9 & 52.6 & 48 & 50.3 \\
\hline Major quinone & MK-9 & MK-8, MK-9 & MK-8, MK-9 & MK-8, MK-9, MK-10 & MK-8, MK-9 & MK-8, MK-9 \\
\hline
\end{tabular}


Cells are Gram-negative-staining, non-motile, obligately aerobic and rod-shaped. Cells are $0.5-0.8 \mu \mathrm{m}$ in width and $1.0-1.5 \mu \mathrm{m}$ in length. Neither cellular gliding movement nor swarming growth is observed. Colonies grown on $1 / 2$ strength R2A agar (Difco) with $75 \%$ artificial seawater are circular, convex and reddish pink. The temperature range for growth is $20-37{ }^{\circ} \mathrm{C}$. Optimal growth occurs at 30 $37^{\circ} \mathrm{C}$; no growth occurs at $4{ }^{\circ} \mathrm{C}$ or $45^{\circ} \mathrm{C}$. The $\mathrm{pH}$ range for growth is 6.5-9.0. $\mathrm{NaCl}$ not required for growth; tolerates concentrations of up to $7 \%(\mathrm{w} / \mathrm{v}) \mathrm{NaCl}$. Catalase- and oxidase-positive. Nitrate is reduced. Tests for alkaline phosphatase, esterase $(\mathrm{C} 4)$, leucine arylamidase, chymotrypsin, acid phosphatase, naphthol-AS-BIphosphohydrolase, $\alpha$-galactosidase and $N$-acetyl- $\beta$-glucosaminidase are positive, but tests for esterase lipase (C8), lipase (C4), valine arylamidase, cystine arylamidase, trypsin, $\beta$-galactosidase, $\beta$-glucuronidase, $\alpha$-glucosidase, $\beta$-glucosidase, $\alpha$-mannosidase and $\alpha$-fucosidase are negative. Dextrin, $\mathrm{N}$-acetyl-D-galactosamine, $\mathrm{N}$-acetylD-glucosamine, L-arabinose, D-fructose, D-galactose, gentiobiose, D-glucose, lactose, lactulose, maltose, methyl $\beta$-D-glucoside, trehalose, furanose, methylpyruvate, D-glucuronic acid, alaninamide, L-alanine, L-alanyl glycine, L-glutamic acid, L-serine and L-threonine are oxidized. The major respiratory menaquinone is MK-9. The cell-wall peptidoglycan contains muramic acid and meso-diaminopimelic acid. Major fatty acid components $(>1.0 \%)$ include iso- $\mathrm{C}_{14: 0}$, anteiso- $\mathrm{C}_{15: 0}$, iso- $\mathrm{C}_{16: 0}$, $\mathrm{C}_{16: 1} \omega 7 c$ and $\mathrm{C}_{16: 0}$.

The type strain, MN1-1006 ${ }^{\mathrm{T}}\left(=\mathrm{KCTC} 23186^{\mathrm{T}}=\mathrm{NBRC}\right.$ $\left.107102^{\mathrm{T}}\right)$, was isolated from a marine ascidian from Sado Island, Japan. The $\mathrm{G}+\mathrm{C}$ content of the genomic DNA of the type strain is $51.4 \mathrm{~mol} \%$.

\section{Acknowledgements}

The authors are grateful to Atsuko Katsuta for her technical assistance. This work was supported by the New Energy and Industrial Technology Development Organization (NEDO). This work was supported in part by the Institute for Fermentation, Osaka, Japan, research grant (2009-2011).

\section{References}

Bartley, G. E. \& Scolnik, P. A. (1995). Plant carotenoids: pigments for photoprotection, visual attraction, and human health. Plant Cell 7 , 1027-1038.

Ezaki, T., Hashimoto, Y. \& Yabuuchi, E. (1989). Fluorometric deoxyribonucleic acid-deoxyribonucleic acid hybridization in microdilution wells as an alternative to membrane filter hybridization in which radioisotopes are used to determine genetic relatedness among bacterial strains. Int J Syst Bacteriol 39, 224229.

Felsenstein, J. (1985). Confidence limits on phylogenies: an approach using the bootstrap. Evolution 39, 783-791.

Fraser, P. D. \& Bramley, P. M. (2004). The biosynthesis and nutritional uses of carotenoids. Prog Lipid Res 43, 228-265.
Harper, J. J. \& Davis, G. H. G. (1979). Two-dimensional thin-layer chromatography for amino acid analysis of bacterial cell walls. Int $J$ Syst Bacteriol 29, 56-58.

Hedlund, B. P., Gosink, J. J. \& Staley, J. T. (1997). Verrucomicrobia div. nov., a new division of the bacteria containing three new species of Prosthecobacter. Antonie van Leeuwenhoek 72, 29-38.

Kasai, H., Katsuta, A., Sekiguchi, H., Matsuda, S., Adachi, K., Shindo, K., Yoon, J., Yokota, A. \& Shizuri, Y. (2007). Rubritalea squalenifaciens sp. nov., a squalene-producing marine bacterium belonging to subdivision 1 of the phylum 'Verrucomicrobia'. Int J Syst Evol Microbiol 57, 16301634.

Katsuta, A., Adachi, K., Matsuda, S., Shizuri, Y. \& Kasai, H. (2005). Ferrimonas marina sp. nov. Int J Syst Evol Microbiol 55, 18511855.

Kimura, M. (1983). The Neutral Theory of Molecular Evolution. Cambridge: Cambridge University Press.

Kumar, S., Tamura, K. \& Nei, M. (2004). MEGA3: Integrated software for molecular evolutionary genetics analysis and sequence alignment. Brief Bioinform 5, 150-163.

Lyman, J. \& Fleming, R. H. (1940). Composition of sea water. J Mar Res 3, 134-146.

Marmur, J. (1961). A procedure for the isolation of deoxyribonucleic acid from micro-organisms. J Mol Biol 3, 208-218.

Mesbah, M., Premachandran, U. \& Whitman, W. B. (1989). Precise measurement of the $\mathrm{G}+\mathrm{C}$ content of deoxyribonucleic acid by highperformance liquid chromatography. Int J Syst Bacteriol 39, 159167.

Mincer, T. J., Jensen, P. R., Kauffman, C. A. \& Fenical, W. (2002). Widespread and persistent populations of a major new marine actinomycete taxon in ocean sediments. Appl Environ Microbiol 68, 5005-5011.

Murray, R. G. E., Doetsch, R. N. \& Robinow, C. F. (1994). Determinative and cytological light microscopy. In Methods for General and Molecular Bacteriology, pp. 21-41. Edited by P. Gerhardt, R. G. E. Murray, W. A. Wood \& N. R. Krieg. Washington, DC: American Society for Microbiology.

Saitou, N. \& Nei, M. (1987). The neighbor-joining method: a new method for reconstructing phylogenetic trees. Mol Biol Evol 4, 406425.

Sandmann, G. (2001). Carotenoid biosynthesis and biotechnological application. Arch Biochem Biophys 385, 4-12.

Scheuermayer, M., Gulder, T. A. M., Bringmann, G. \& Hentschel, U. (2006). Rubritalea marina gen. nov., sp. nov., a marine representative of the phylum 'Verrucomicrobia', isolated from a sponge (Porifera). Int J Syst Evol Microbiol 56, 2119-2124.

Schleifer, K. H. \& Kandler, O. (1972). Peptidoglycan types of bacterial cell walls and their taxonomic implications. Bacteriol Rev 36, 407477.

Shindo, K., Mikami, K., Tamesada, E., Takaichi, S., Adachi, K., Misawa, N. \& Maoka, T. (2007). Diapolycopenedioic acid xylosyl ester, a novel glyco- $\mathrm{C}_{30}$-carotenoic acid produced by a new marine bacterium Rubritalea squalenifaciens. Tetrahedron Lett 48, 27252727.

Thompson, J. D., Gibson, T. J., Plewniak, F., Jeanmougin, F. \& Higgins, D. G. (1997). The CLUSTAL_X windows interface: flexible strategies for multiple sequence alignment aided by quality analysis tools. Nucleic Acids Res 25, 4876-4882.

Wayne, L. G., Brenner, D. J., Colwell, R. R., Grimont, P. A. D., Kandler, O., Krichevsky, M. I., Moore, L. H., Moore, W. E. C., Murray, R. G. E. \& other authors (1987). International Committee on Systematic Bacteriology. 
Report of the ad hoc committee on reconciliation of approaches to bacterial systematics. Int J Syst Bacteriol 37, 463-464.

Weisburg, W. G., Barns, S. M., Pelletier, D. A. \& Lane, D. J. (1991). $16 \mathrm{~S}$ ribosomal DNA amplification for phylogenetic study. J Bacteriol 173, 697-703.

Yokota, A., Tamura, T., Nishii, T. \& Hasegawa, T. (1993). Kineococcus aurantiacus gen. nov., sp. nov., a new aerobic, gram-positive, motile coccus with diaminopimelic acid and arabinogalactan in the cell wall. Int J Syst Bacteriol 43, 52-57.
Yoon, J., Matsuo, Y., Matsuda, S., Adachi, K., Kasai, H. \& Yokota, A. (2007). Rubritalea spongiae sp. nov. and Rubritalea tangerina sp. nov., two carotenoid- and squalene-producing marine bacteria of the family Verrucomicrobiaceae within the phylum 'Verrucomicrobia', isolated from marine animals. Int J Syst Evol Microbiol 57, 2337-2343.

Yoon, J., Matsuo, Y., Matsuda, S., Adachi, K., Kasai, H. \& Yokota, A. (2008). Rubritalea sabuli sp. nov., a carotenoid- and squalene-producing member of the family Verrucomicrobiaceae, isolated from marine sediment. Int J Syst Evol Microbiol 58, 992-997. 